\title{
Tropicalizing Frankenstein in Latin America. A tale about PROMISING TECHNOLOGIES AND APOCALYPTIC ROBOTS
}

\author{
Tropicalizando Frankenstein en América Latina. Un cuento sobre tecnologías \\ PROMETEDORAS Y ROBOTS APOCALIPTICOS
}

David Ramírez Plascencia

University of Guadalajara; david.ramirez@redudg.udg.mx

\begin{tabular}{|c|c|}
\hline His & it \\
\hline Recibido: 19-03-2019 & \multirow{9}{*}{$\begin{array}{l}\text { Frankenstein is not an exclusive character belonging to the realm of the Gothic } \\
\text { narrative, but a vivid element that has evolved and adapted to diverse social con- } \\
\text { texts and geographies. Mary Shelley's work has endured the passing of time and } \\
\text { now is a symbol of the popular culture. In this paper, I look to understand Mary } \\
\text { Shelley's Frankenstein influence on people's attitudes regarding technology and } \\
\text { science, particularly artificial intelligence and robots. How the negative visions } \\
\text { and fears about the misuse of science to break traditional moral and religious } \\
\text { boundaries are still present in popular culture. Fieldwork will be focused on re- } \\
\text { viewing several Latin American newspapers and magazine articles in Spanish and } \\
\text { Portuguese published on the Internet. As final outcomes will show, Mary Shelley's } \\
\text { Frankenstein still continues influencing people's imagination about science and } \\
\text { technology, even in technically less developed regions. }\end{array}$} \\
\hline Acept & \\
\hline Publicad & \\
\hline Keywords & \\
\hline Latin America & \\
\hline elligence & \\
\hline 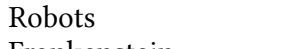 & \\
\hline & \\
\hline & \\
\hline
\end{tabular}

\section{Resumen}

Palabras clave

América Latina

Inteligencia artificial

Robots

Frankenstein

Ética de la ciencia

\begin{abstract}
Frankenstein no es un personaje exclusivo del ámbito de la narrativa gótica, sino un elemento vivo que ha evolucionado y se ha adaptado a diversas geografías y contextos sociales. El trabajo de Mary Shelley ha perdurado el paso del tiempo, consolidándose como un símbolo preponderante de la cultura popular. En este artículo, busco entender la influencia del Frankenstein en las actitudes de las personas con respecto a la tecnología y la ciencia, en particular la inteligencia artificial y los robots; así como los temores sobre el uso indebido de la ciencia y el rompimiento de los límites morales y religiosos tradicionales. El trabajo de campo se centrará en la revisión de diversos artículos de periódicos y revistas publicados en medios latinoamericanos y difundidos en Internet. Los resultados mostrarán como la obra de Mary Shelley continúa influyendo en la imaginación de la gente sobre ciencia y tecnología en América Latina.
\end{abstract}

Ramírez Plascencia, David (2020). Tropicalizing Frankenstein in Latin America. A tale about promising technologies and apocalyptic robots. Athenea Digital, 20(2), e2647. https://doi.org/10.5565/rev/athenea.2647

\section{Introduction}

As an undeniable fact, Frankenstein is no longer a mere character that is restricted to the fantastic narrative, but a vivid element that has evolved and adapted to diverse social contexts and geographies. Mary Shelley's creation has endured the passing of time and now is an archetypal figure in popular culture (Friedman \& Kavey, 2016). It has appeared in numerous movies, TV series and comics (Braid, 2017), and it has inspired other literary works. In our Internet era, it is always present across "memes" and other multimedia elements (Rollins, 2018). But the novel has not been immune to countless mis-readings, adaptations and reinterpretations. Indeed, most of the popular versions 
shared on the media differ significantly from the original work. Many people still believe that the monster's name is Frankenstein, for example. Even though it has no name, and it is frequently called daemon or creature across the novel. However, as Chris Baldick points out in his work In Frankenstein's Shadow, this material is not "a supplementary component of the myth; it is the myth." (Ball, 2017). This unending reinvention of the creature reinforces its vitality and validity in modern societies. Societies that, from a certain point of view, share many affinities and ideas with the XIX century, when Mary Shelley's work was born. One of them is the fascination and fear about technology.

The XIX century in Europe was marked not only by the rise of the United Kingdom as a colonial empire, but also of the huge scientific and economic shift. The development of diverse machines powered by steam had a significant impact in the consolidation of the Industrial Revolution which triggered the spread of textile factories and mills. Railroads spread across the empire providing a more secure and quicker form of travelling which took the Victorian culture and art to every remote corner of the empire. During this time, the people witnessed the invention of diverse communication and entertainment machineries like the cinema, telegraph, telephones, automobiles and airplanes. Even the foundations of the church were shaken by the theoretical postulations of Darwin's theory of evolution. But, ironically, it was this century that gave birth to important horror literature icons like Frankenstein and Dracula, which portray a dark, frightening, and unexpectedly romantic vision of the world. Most of this artistic fascination was based not only in medieval legends as the case of Dracula, but also on the vertiginous scientific and technological shift of the period.

People were captivated by the display of "pictures in movement" (Cinema), but at the same time, these kinds of devices challenged their inherited conceptions about the limits of what is possible or allowed, and what is forbidden to surpass. XIX writers were not reluctant to this fascination towards science and technology. As in the case of Mary Shelley's work, she was inspired by notorious discoveries of Luigi Galvani related with electricity and the muscular movement, Galvanism (Finger \& Law, 1998). Later, in her novel, the electricity became the crucial element that allowed Victor Frankenstein "to infuse a spark of being" to his creature (Shelley, 2012: 102). Another important source of scientific inspiration for her novel was the study of medicine, anatomy and natural philosophy, an academic hobby shared with her husband, Percy Shelley (Goulding, 2002). Percy Shelley and Mary Shelley's father, William Godwin were influenced by Erasmus Darwin's ideas, who considered science as an important instrument to bring light into the social and private human sphere. Erasmus (Charles Darwin's grandfather), was a remarkable scientific, medic and philosopher. He was a 
founding member of the Lunar Society, an academic organization, which included renowned scientists like Mathew Boulton and James Watt. This organization played a key role in the development of important innovations in steam power, chemical manufacture, optics, geology and electricity (Knellwolf \& Goodall, 2017). However, despite this scientific background, Mary Shelley's Frankenstein has arrived into our time, puzzlingly, as a symbol of caution against all the vertiginous technological changes, discouraging our optimism about the positive impact of science in our life. This paper aims to understand Mary Shelley's Frankenstein's influence on people's considerations and attitudes regarding technological advances, particularly artificial intelligence and robots. How the negative visions and fears about the misuse of science to break traditional moral and religious boundaries are still present in popular culture, even in remote contexts like Latin America.

Despite that there is not a universal consensus about the concept of popular culture, in terms of this paper, this word will refer to a particular element that is disseminated and consumed by a large number of people (Hinds Jr., 2006). It is not the case that this text omits the existence of other important definitions, such as the one based on the dichotomy among elite culture and popular culture (Kidd, 2017). But to understand popular culture as an element that is widely consumed, regardless what the economic or social status of the consumers is, provides a more malleable definition that could embrace modern cultural goods widely shared among all the social extracts like digital memes. Fieldwork will be focused on reviewing Latin American newspapers and magazine articles in Spanish and Portuguese published on the Internet. After a careful examination, 14 articles were selected and registered under a simple coding system to be referenced in the text. For example, $A 5$ will mean $(A=A r t i c l e$, and $5=$ the ordinal number). For more information see Appendix.

The main objective is to analyze some recurrent topics associated with Mary Shelley's novel: (1) references to Frankenstein in AI and robotics articles, (2) fears and hopes about scientific and technological research, and (3) the establishment of moral and legal patrons to guide scientific research. As final outcomes will show, Mary Shelley's Frankenstein still influences people's imaginings about science and technology, even in such different and technologically less developed contexts like Latin American countries. In this context, emergent technologies like artificial intelligence and robotics are not invulnerable to this impact, but on the contrary, these technologies reinforce those fears, concerns and hopes. 


\section{Frankenstein in academia and popular culture}

Mary Shelley's novel is an ethical paradigm of the possible terrible consequences of technological development (Nagy, Wylie, Eschrich, \& Finn, 2018). It is a warning for those men and women of science who wish to break moral and religious limits, such as playing God (Peters, 2018). It was used for example to criticize the Manhattan project and the development of the atomic bomb, in words of James Bryant Conant, president of Harvard University and member of the National Defense Research Committee, "We built a one Frankenstein" (Ziolkowski, 1981, p. 37). The postwar nuclear arms race has carried this negative allegory as well. Nuclear weapons are described as "Frankenstinian monsters" (Hecht, 2003, p. 4). In medical and biological fields, Mary Shelley's creature is used as an argument to negatively frame contemporary researches like human cloning and organ transplants. Some people have described organ donations and transplantation as criminal abominations (O’Neill, 2006). Frankenstein has been invoked in public debate about embryo research in the last three decades. In November 1987, The Sun newspaper published an article in which a big Frankenstein illustration accompanied a brief text promoting limits and controls over embryonic investigation (Mulkay, 2016). In 2008, when the UK parliament passed a law allowing the development of human-animal hybrids or human admixed embryos, the president of the Bishops' Conference of Scotland, Cardinal O'Brien, characterized this kind of research as having "Frankenstein proportions" (Bizony, 2009, p. 84). As these cases illustrate, the creature of Frankenstein has been used in academic and political deliberation as proof that no matter the good intentions behind the scientific research: the cure of mortal diseases, the improvement of people's social conditions, human longevity and so on, there will always be terrible consequences for those who transgress the established boundaries of good and evil (Hecht, 2003). The final outcome will always bring horrible consequences not only for the scientists, but to all mankind. It is not an accessory fact that Mary Shelley used a complementary title for her work The Modern Prometheus. The allusion to this Ancient Greek myth in which Prometheus, a titan, stole fire to improve humans' miserable condition, but in the end, both the titan and humanity were punished by Zeus as a consequence for this religious transgression. It is a clear statement of how good intentions can translate into terrible outcomes.

This ethical discussion about scientific research is reflected as well in popular culture. Comics or movies are not just innocuous entertainment, but unintentionally or not, they may shape our conceptions about science. In many horror movies, for exam-

ple, scientists are seen as the cause of social and natural catastrophes (Tudor, 1989). This particular association among science and perils have caused a collective fear 
about the social consequences of technological innovation. The connection of Frankenstein with misuse of science that causes harm may serve to reinforce negative public opinions regarding scientific endeavors. Mary Shelley's work has been the subject of diverse academic and political interpretations, many of them are related with ethical issues, particularly with setting boundaries to scientific research. The following paragraph describes some of them.

Some scholars, believe that we have to take Frankenstein's warnings more seriously. Christopher DiCarlo (2016) advises in his Frankenstein effect that many catastrophes in scientific research occur because we are so concerned with what science can achieve, that we forget to consider what may be the final outcome of that research. In the race to achieve our ambitions and goals, we tend to deny alternative scenarios that portray terrible consequences or tribulations. Another interpretation relies on the idea of playing God. In many passages of the novel, Victor Frankenstein called his creature a daemon, "the filthy daemon to whom I had given life." (Shelley, 2012, p. 132). This is a clear allusion to how the misuse of science breaks some religious norms: to give life, as Jesus did with Lazarus, and not to accept God's will, as Victor cannot assume the death of his beloved ones (Adams, 2001). Therefore, the product of this mislead science, The creature, is an evil product, out of the grace of God. Other views (Davies, 2004), interpret Victor Frankenstein's tragedy as a consequence of the separation in between the subject and the society, in where the scientists lose their moral principles, captured by madness and ambition. As in the voice of Dr. Frankenstein, "From my infancy I was imbued with high hopes and a lofty ambition; but how am I sunk!" (Shelley, 2012, p. 348). Another known interpretation considers the main argument of the novel as a tale about how slaves turn against their master (Alcalá, 2018). A passage of the novel shows this sort of insubordination "You are my creator, but I am your master; -obey!" (Shelley, 2012, p. 208). This is a recurrent argument in science fiction movies as well: Matrix, Alien Covenant and 2001: A Space Odyssey. Even the word Robot, from the Czech word, robota (forced labor), is a clear reference to a master-slave relation. For that reason, it is not unusual that the word "Frankenstein" is frequently associated with academic and newspaper articles related with artificial intelligence and robots.

Robots have had a long presence in arts and popular culture. Its construction could be dated to the Ancient Greeks and Leonardo da Vinci. Robots play a key role in modern factories, assembling diverse goods from mobile devices to smart TVs. But what is different in present times is the growing presence of social robots in our daily life (Höflich \& El Bayed, 2015). Regarding Artificial Intelligence (AI), the first notions of this technology appeared in Alan Turing's works in 1950. Turing tried to compre- 
hend if we were able to develop computer programs that are capable to think like humans. Technically, AI is the implementation of systems that are capable of solving issues that require human reasoning (Tseng \& Ting, 2013). Actually, AI and robots have left laboratories and their presence is more persistent in economic and social activities: from online customer services applications to domestic and medic robots. However, AI has rised ethical worries (Canavan, 2015). Once again, popular culture, particularly science fiction works, stand as a reference to illustrate public debate. The association of the Frankenstein monster with robotic and artificial intelligence dates since many decades ago (Lehman-Wilzig, 1981), long before the development of the World Wide Web, and therefore social media and mobile devices. Artificial Intelligence has been seen as a promising technology that could help governments to resolve traditional and complex problems like urban criminality and public services logistics. A computer that is able to reason and to take decisions could be a great ally when dealing with situations in where it is mandatory to process a huge amount of data and to consider multiple variables in a matter of seconds. However, the fears about an independent machine that could make choices by itself is still present in political and academic considerations (Nomura, Sugimoto, Syrdal, \& Dautenhahn, 2012; Sundar, Waddell, \& Jung, 2016). In this context, Frankenstein is a vivid reminder of how the creation could turn against the creator, or how humans can lose the control over the technological advances: atomic energy, robots or biotechnology. Those technologies are currently the subject of the public debates not only because of their potential benefits, but because of their real or illusory risks and perils. Even many people question that as we abandon the traditional boundaries among what is ethically right about human reproduction processes, can we still think of us as human beings, or are we arriving to a posthuman age, in where novel legal and ethical parameters are required? (Burkett, 2012) (McQueen, 2014).

\section{Tropicalizing a Classic. Frankenstein in Latin America}

In spite of the deep lacks in digital infrastructure, Latin America has experienced important advances in Internet connectivity and a massive spread of mobile devices, particularly among the young ones who spend most of their time on social media platforms like YouTube, Facebook and Snapchat. Governments around the region have made important efforts not only to modernize public services using information technologies, but to eradicate the digital divide among their citizens. Beside the barriers, in recent years, it has been common to observe in diverse cities across the region the use of drones and robots in public agencies and manufacturing companies (Ruiz-del-Solar $\&$ Weitzenfeld, 2012). In addition, in the last decades, there has been a growing atten- 
tion about artificial intelligence (Velasco Sánchez, 1996; Cuadrado Alvarado, 2003; Campanario, 2016). Even in the educative sector, there is a rising interest to offer coding courses in elementary school and to promote robotic competitions. The irruption of these fresh technologies, however, has brought fears and concerns, particularly in the labor sector. Many people have perceived the proliferation of robots in the manufacture industry as a threat for their employments (Bailey, 2017). Once again, as in Mary Shelley's novel, a promising technology could turn into a threatening situation. Frankenstein is a recurrent topic in academia and media, particularly in debates about the incorporation of information technologies into daily life, and as it happens in other countries, most of the discussions turn around the possible benefits and the potential risks. Some authors worry about the latent abuse of science by international corporations or the army to exert a determinant martial or economic power (Urrego, 2005), as in the case of global corporations that use technology and the chronic public corruption in Latin America to dominate the people and steal the natural resources. For many people, robots represent the materialization of traditional nightmares and fears in where humans break religion limits and play God, creating life as in the case of Doctor Frankenstein (Miscione, 2015). In Table 1, it is possible to observe a list of the most recurrent topics in Latin American newspapers and magazines related with Frankenstein, AI and robotics.

\begin{tabular}{|c|c|c|c|c|}
\hline & $\begin{array}{l}\text { Reference to } \\
\text { Frankenstein }\end{array}$ & Fears & Hopes & $\begin{array}{c}\text { Ethical or } \\
\text { Legal Norms }\end{array}$ \\
\hline 1 & $\begin{array}{l}\text { Our own creation could } \\
\text { destroy us (A3) (A7) } \\
\text { (A9) (A10) (A11) }\end{array}$ & $\begin{array}{l}\text { Artificial Intelligence } \\
\text { could destroy the hu- } \\
\text { man race (A2) (A3) }\end{array}$ & $\begin{array}{c}\text { To support people with } \\
\text { disabilities (A1) }\end{array}$ & $\begin{array}{c}\text { To protect privacy (A2) } \\
\text { (A5) (A14) }\end{array}$ \\
\hline 2 & $\begin{array}{c}\text { To commit scientific re- } \\
\text { search that surpasses } \\
\text { Nature Laws (A10) (A11) } \\
\text { (A6) }\end{array}$ & $\begin{array}{c}\text { Robots will replace hu- } \\
\text { mans in factories (A3) } \\
\text { (A4) (A7) (A12) (A14) }\end{array}$ & $\begin{array}{l}\text { The use of Artificial In- } \\
\text { telligence to improve } \\
\text { medical diagnosis (A12) }\end{array}$ & $\begin{array}{c}\text { To create a special tax } \\
\text { for companies that use } \\
\text { Robots. (A3) }\end{array}$ \\
\hline 3 & $\begin{array}{l}\text { Improper use of scien- } \\
\text { tific research (A12) }\end{array}$ & $\begin{array}{c}\text { Artificial Intelligence } \\
\text { without emotions and } \\
\text { social conscience (A10) } \\
\text { (A11) }\end{array}$ & & $\begin{array}{l}\text { Avoid regulation of AI } \\
\text { and robotic technologies } \\
\text { (A4) (A7) / To regulate } \\
\text { (A11) (A13) (A14) }\end{array}$ \\
\hline
\end{tabular}

Table 1. Recurrent topics in Latin American press about AI and Robots. All Codes refer to the appendix

\section{References to Frankenstein in $\mathrm{Al}$ and robotic articles}

Some of the consulted articles, intentionally or not, employ the word Frankenstein in their headlines. For example: Frankenstein, la singularidad y el fin de la humanidad / Frankenstein, the singularity and the end of humanity (A9) (Fernández, 2018). or Por 
qué la Inteligencia Artificial necesita clases de ética: Hemos creado un Frankenstein / Why Artificial Intelligence needs classes in ethics: We have created a Frankenstein (A10) (Pardo, 2018). In both cases, the headlines show a clear association amid the figure of Frankenstein and the existence of a complexed or dangerous situation. Other headlines follow a similar criteria but, in this case, it is the artificial intelligence which is linked with the idea of danger: La inteligencia artificial, ¿va a salvar a la humanidad o la esclavizará? / Artificial intelligence, will it save humanity or enslave it? (A7) (Bellucci, 2018). Here it is possible to observe a recurrent idea inspired in Frankenstein: the creation turns against its creator. Other articles consider this dilemma as well. "Nos inquieta la posibilidad de que nuestras creaciones sean la fuente de nuestra destrucción / We are disturbed by the possibility that our creations will be the source of our destruction" (A3) (Amador, 2017, para. 02) and "(Tememos) a situaciones hipotéticas que representan un peligro de extinción para la especie humana / (We fear) hypothetical situations that represent a danger of extinction for the human species." (A10) (Guerrero, 2018, para. 18). From a certain point of view, people consider Artificial Intelligence as a monster, because it is based in a science that is only accessible for a limited number of people... "Hemos creado un monstruo de Frankenstein porque, salvo en el caso de expertos, la complejidad de los algoritmos y de los sistemas de toma de decisiones automática es tal que sólo algunos expertos pueden comprenderlo / We have created a Frankenstein monster because, except in the case of experts, the complexity of algorithms and automatic decision-making systems is such that only few experts can understand it.” (A11) (Pardo, 2018, para. 13).

\section{Hopes and fears about scientific and technological research}

Many of the articles emphasize both the potential benefits and the perils and problems of using AI and robots. Amid the most promising issues are the development of software that will allow people to control devices only with the use of brain signals (A1) (Robots made in Chile buscan revolucionar la industria local, 2015), to create robots to assist people with disabilities such as autism (AI), or to develop AI applications that support medical diagnosis (A12) (Peña, 2018). However, there are many fears and concerns about this invasion of robots and machine learning applications. One of the most recurrent anxieties is related to the labor sector (A3) (Amados, 2017) (A9) (Fernández, 2018) (A12) (Peña, 2018) (A14) (Sánchez, 2018). This fear is one the most important for Latin Americans due to the fact that many people work in big factories and manufacturing companies. These anxieties are visible in the following extracts, "El miedo a los robots ha llegado a la Economía. ¿Qué efectos tendrá una adopción masiva de robots sobre el mercado laboral? / The fear of robots has reached the Economy. What effects will a massive adoption of robots have on the labor market?" (A3) (Amador, 2017, 
para. 1) and 'La revolución tecnológica se refleja en la pérdida de puestos laborales, algo que podría incrementarse en los próximos años / the technological revolution is reflected in the loss of jobs, something that could increase in the coming years" (A7) (Bellucci, 2018, para. 9). However, there are other reservations related to the arrival of $\mathrm{AI}$ and robots in Latin America, some refer to the lack of emotions and compassion of AI applications. Many people worry about how many important decisions will be taken by AI systems developed on a costs-benefits understanding without considering other variables that humans do. As the following fragment points out, "El problema central de una súper I.A. es que muy probablemente sería una inteligencia puramente pragmática, carente de las emociones y la conciencia social que intervienen en los procesos de decisión de los seres humanos / The central problem of a super I.A. is that it would most likely be a purely pragmatic intelligence, lacking the emotions and social conscience that intervene in the decision processes of human beings." (A10) (Guerrero, 2018, para. 27).

\section{The establishment of moral and legal patrons to guide scientific research}

Another important topic reflected in the material is the concern about the regulations or moral patrons to guide scientific research. The eruption of new devices like drones makes this topic crucial, so it is expressed in the following fragment "La actividad de los robots volátiles (drones) no está regulada en casi ningún lugar del mundo, y no son precisamente juguetes / The activity of flying robots (Drones) is hardly regulated anywhere in the world, and they are not exactly toys." (A2) (Torres, 2015, para. 1). Some articles see a potential lack of proper legal and ethical frameworks that must be created to have a harmonious relation with robots and other emerging technologies (A11) (Pardo, 2018) (A12) (Peña, 2018) (A13) (Riquelme, 2018). As the following fragment asserts, "algo que es básico es un marco regulatorio y ético para que se pueda dar una sana interacción entre los humanos y las maquinas inteligentes / An obvious requirement is a regulatory and ethical framework so that a healthy interaction between humans and intelligent machines can take place" (A14) (Sánchez, 2018, para. 50). In this context, the invasion of privacy is one of the most recurrent issues (A2) (Torres, 2015) (A5) (Sá Elias, 2017). As we can appreciate in this fragment from an article in Portuguese published in Brazil, "E isto tem profundo impacto em relação a autodeterminação informativa, o direito constitucional da intimidade e a privacidade / And this has a profound impact on informational self-determination, the constitutional right to privacy and intimacy." (A5) (Sá Elias, 2017, para. 15). However, it is possible to observe dissident voices that claim for a more cautious approach to the regulation of these kinds of technologies (A4) (Cordeiro, 2017) (A7) (Bellucci, 2018). Some arguments emphasize that we need to focus not on the technology, but on how we use it. "Las tecno- 
logías no tienen moral, es decir, no se las puede tildar de buenas o malas. Después está el uso y aplicación que hacen las personas de ellas / Technologies do not have morals, that is, they cannot be labeled as good or bad. Then there is the use and application that people make of them." (A7) (Bellucci, 2018).

\section{Conclusion}

In 2018, with many public and academic events across the globe to celebrate the 200th anniversary of Mary Shelley's Frankenstein (Larabee, 2018), the figure of Frankenstein is still relevant not only to the entertainment sector, but to the public debate about the legal and ethical boundaries of technological and scientific research. Now, with the massive spread of Artificial Intelligence applications and robots into businesses and domestic environments, the figure of Frankenstein is present in the public debate about the potentials and pitfalls of incorporating these emerging technologies into daily life. Besides, popular culture products like TV series or comics do not have the ultimate aim of delivering scientific facts to the public. They have a deep impact on people's opinions about technological advances like domestic robots or artificial intelligence. Governments and citizens in Latin America are fascinated with this technology but, at same time, they have doubts and concerns about the negative impacts of socializing these technological advances. These anxieties have been reinforced by TV shows in Netflix, like The Frankenstein Chronicles for example, (Carrión, 2018) and Hollywood productions as in the case of Robocop and Terminator (Oliveros Aya, 2015).

In this context, popular culture helps people to speculate, avoiding the limits of formal science, about the proper or ethical use of technological development (O'Neill, 2006). These ethical considerations regarding science do not belong to a specific social group, but they influence the public debate and have a great impact on the political and legal sphere. Many regulations that limit the incursion of science in diverse fields like biotechnology or artificial intelligence are not based on formal studies, but in prejudices and fears borrowed from Gothic and science fiction works, in where scientific data is mixed with fictional facts, moral and religious ideas about what is reasonably forbidden or allowed about scientific research (van der Laan, 2010). What the analysis of these articles show is how Latin Americans, as people living in developing countries, are worried by the incorporation of emerging technologies. Once again, Frankenstein is used as a warning to those people who want to play God and to build thinking robots (Gopnik, 2017). Technology has always fascinated and scared humans since probably the discovery of fire, as the myth of Prometheus reveals us. In this case, we are not so different than the people who lived in the XIX century. What is different 
in our context is that Artificial Intelligence and robots have replaced electricity and steam, as sources of fears and concerns. Frankenstein, for the critics of these novel technologies, is no longer a creature built from several human corpses, but from metal, computer chips and sophisticated computer systems based on Artificial Intelligence.

\section{Appendix. Latin American Articles}

\begin{tabular}{|c|c|c|c|}
\hline & Article & Country & CODE \\
\hline 1 & $\begin{array}{l}\text { Robots made in Chile buscan revolucionar la industria local / Robots } \\
\text { made in Chile seek to revolutionize the local industry. (2015) }\end{array}$ & Chile & A1 \\
\hline 2 & $\begin{array}{l}\text { La inteligencia artificial no es peligrosa; nosotros, sí / Artificial intelligen- } \\
\text { ce is not dangerous; we, yes (Torres, 2015) }\end{array}$ & Argentina & A2 \\
\hline 3 & $\begin{array}{l}\text { Victor Frankenstein, los robots y la redistribución en un mundo automa- } \\
\text { tizado / Victor Frankenstein, robots and redistribution in an automated } \\
\text { world (Amador, 2017) }\end{array}$ & $\begin{array}{l}\text { Latin } \\
\text { America }\end{array}$ & A3 \\
\hline 4 & $\begin{array}{l}\text { Seria prematuro tentar regulamentar agora a inteligência artificial / It } \\
\text { would be premature to regulate artificial intelligence (Cordeiro, 2017) }\end{array}$ & Brazil & A4 \\
\hline 5 & $\begin{array}{l}\text { Algoritmos e inteligência artificial exigem atenção do Direito / Algori- } \\
\text { thms and Artificial Intelligence Require Law's Attention (Sá Elias, 2017). }\end{array}$ & Brazil & A5 \\
\hline 6 & $\begin{array}{l}\text { Mary Shelley vuelve "remasterizada”, a } 200 \text { años de inventar Franken- } \\
\text { stein / Mary Shelley returns "remastered”, } 200 \text { years of inventing } \\
\text { Frankenstein (Bederman, 2018). }\end{array}$ & Argentina & A6 \\
\hline 7 & $\begin{array}{l}\text { La inteligencia artificial, ¿va a salvar a la humanidad o la esclavizará? / } \\
\text { Artificial intelligence, will save humanity or enslave it? (Bellucci, 2018). }\end{array}$ & Argentina & A7 \\
\hline 8 & $\begin{array}{l}\text { Todos los rostros de Frankenstein, el monstruo más amado / All the } \\
\text { faces of Frankenstein, the most beloved monster (Debowicz, 2018). }\end{array}$ & Argentina & A8 \\
\hline 9 & $\begin{array}{l}\text { El legado de la Inteligencia Artificial en América Latina / The legacy of } \\
\text { Artificial Intelligence in Latin America (Fernández, 2018). }\end{array}$ & Mexico & A9 \\
\hline 10 & $\begin{array}{l}\text { Frankenstein, la singularidad y el fin de la humanidad / Frankenstein, } \\
\text { the uniqueness and the end of humanity (Guerrero, 2018) }\end{array}$ & Mexico & A10 \\
\hline 11 & $\begin{array}{l}\text { Por qué la Inteligencia Artificial necesita clases de ética: "Hemos creado } \\
\text { un Frankenstein.” / Why Artificial Intelligence needs ethics classes: "We } \\
\text { have created a Frankenstein" (Pardo, 2018) }\end{array}$ & Mexico & A11 \\
\hline 12 & $\begin{array}{l}\text { Frankenstein o Alexa: la inteligencia artificial en prospectiva / Frankens- } \\
\text { tein or Alexa: artificial intelligence in prospective (Peña, 2018) }\end{array}$ & Colombia & A 12 \\
\hline 13 & $\begin{array}{l}\text { ¿De quién son los datos que usa la Inteligencia Artificial? / Whose data } \\
\text { is Artificial Intelligence using? (Riquelme, 2018). }\end{array}$ & Mexico & A13 \\
\hline 14 & $\begin{array}{l}\text { Cuando la inteligencia artificial nos supere / When the artificial intelli- } \\
\text { gence surpasses us (Sánchez, 2018) }\end{array}$ & Mexico & A14 \\
\hline
\end{tabular}




\section{References}

Adams, Will W. (2001). Making Daemons of Death and Love: Frankenstein, Existentialism, Psychoanalysis. Journal of Humanistic Psychology, 41(4), 57-89. https://doi.org/10.1177/0022167801414004

Alcalá, Roberto del V. (2018). Monstrous contemplation: Frankenstein, Agamben, and the politics of life. Textual Practice, 32(4), 611-628. https://doi.org/10.1080/0950236X.2016.1256343

Amador, Dego (2017, mayo 9). Victor Frankenstein, los robots y la redistribución en un mundo automatizado [Blog]. Foco Económico. Retrieve from http://focoeconomico.org/2017/05/09/victor-frankenstein-los-robots-y-laredistribucion-en-un-mundo-automatizado/

Bailey, Ronald (2017, June 6). Are Robots Going to Steal Our Jobs? Reason.Com. Retrieved from https://reason.com/archives/2017/06/06/are-robots-going-tosteal-our

Ball, Philip (2017, April 20). "Frankenstein" Reflects the Hopes and Fears of Every Scientific Era. The Atlantic. Retrieved from https://www.theatlantic.com/science/archive/2017/04/franken-science/ $\underline{523560 /}$

Bederman, Uriel (2018, agosto 12). Mary Shelley vuelve "remasterizada ", a 200 años de inventar Frankenstein. La Nación. https://www.lanacion.com.ar/2161557mary-shelley-vuelve-remasterizada-a-200-anos-de-inventarfrankensteinBellucci, Marcelo (2018, febrero 18). La inteligencia artificial, ¿va a salvar a la humanidad o la esclavizará? El Clarín. Retrieve from https://www.clarin.com/sociedad/inteligencia-artificial-va-salvar-humanidadesclavizara 0 B1kEPODPG.html

Bizony, Piers (2009). Frankenstein reclaimed - [engineering philosophy]. Engineering Technology, 4(5), 82-85. https://doi.org/10.1049/et.2009.0519

Braid, Barbara (2017). The Frankenstein Meme: Penny Dreadful and The Frankenstein Chronicles as Adaptations. Open Cultural Studies, 1(1), 232-243. https://doi.org/10.1515/culture-2017-0021

Burkett, Andrew (2012). Mediating Monstrosity: Media, Information, and Mary Shelley's "Frankenstein." Studies in Romanticism, 51(4), 579-605.

Campanario, Sebastián (December, 2016). Inteligencia artificial: ¿cómo modifica la vida cotidiana? La Nación. Retrieved from https://www.lanacion.com.ar/1967806inteligencia-artificial-como-modifica-la-vida-cotidiana

Canavan, Gerry (2015). Capital as Artificial Intelligence. Fournal of American Studies, 49(4), 685-709. https://doi.org/10.1017/S002187581500167X

Carrión, Jorge (2018, March 3). Frankenstein cumple 200 años: del monstruo de Mary Shelley al de Netflix. The New York Times. Retrieved from https://www.nytimes.com/es/2018/03/03/frankenstein-cumple-200-anos-delmonstruo-de-mary-shelley-al-de-netflix/

Cordeiro, Sthepany (2017, enero 4). Seria prematuro tentar regulamentar agora a inteligência artificial. Portal Intelectual. Retrieve from 
https://portalintelectual.com.br/portal/seria-prematuro-tentar-regulamentaragora-a-inteligencia-artificial/

Cuadrado Alvarado, Alfonso (2003). El imaginario de la creación de vida artificial y los personajes virtuales. Comunicaciónrevista Internacional de Comunicación Audiovisual, Publicidad y Estudios Culturales, 2, 13-28.

Davies, Hugh (2004). Can Mary Shelley's Frankenstein be read as an early research ethics text? Medical Humanities, 30(1), 32-35. https://doi.org/10.1136/jmh.2003.000153

Debowicz, Maia (2018, junio 30). Todos los rostros de Frankenstein, el monstruo más amado. Infobae.

https://www.infobae.com/america/cultura-america/2018/06/30/todos-losrostros-de-frankenstein-el-monstruo-mas-amado/

DiCarlo, Christopher (2016). How to Avoid a Robotic Apocalypse: A Consideration on the Future Developments of AI, Emergent Consciousness, and the Frankenstein Effect. IEEE Technology and Society Magazine, 35(4), 56-61. https://doi.org/10.1109/MTS.2016.2618718

Fernández, Alejandro (2018, agosto 31). El legado de la Inteligencia Artificial en América Latina. Forbes. Retrive from https://www.forbes.com.mx/el-legadode-la-inteligencia-artificial-en-america-latina/

Finger, Stanley \& Law, Mark B. (1998). Medicine in the Arts: Karl August Weinhold and His "Science" in the Era of Mary Shelley's Frankenstein: Experiments on Electricity and the Restoration of Life. Fournal of the History of Medicine and Allied Sciences, 53(2), 161-180. https://doi.org/10.1093/jhmas/53.2.161

Friedman, Lester D., \& Kavey, Allison B. (2016). Monstrous Progeny: A History of the Frankenstein Narratives. New Brunswick, New Jersey: Rutgers University Press.

Gopnik, Alison (2017, July). Making AI More Human. Scientific American, 316(6) 60-65.

Goulding, Christopher (2002). The Real Doctor Frankenstein? Journal of the Royal Society of Medicine, 95(5), 257-259. https://doi.org/10.1177/014107680209500514

Guerrero Mothelet, Verónica (2018, febrero 27). Frankenstein, la singularidad y el fin de la humanidad. Paradigma XXI. Retrieve from http://blogs.ciencia.unam.mx/ paradigmaxxi/2018/02/27/frankenstein-la-singularidad-y-el-fin-de-lahumanidad/

Hecht, Gabrielle (2003). Globalization meets frankenstein? Reflections on terrorism, nuclearity, and global technopolitical discourse. History and Technology, 19(1), 1-8. https://doi.org/10.1080/0734151022000042243

Hinds Jr, Harold (2006). A holistic approach to the study of popular culture: context, text, audience, and recoding. In Harold Hinds Jr, Marilyn F. Motz, \& Angela M. S. Nelson (Eds.), Popular Culture Theory and Methodology: A Basic Introduction ( $1^{\text {st }}$ ed., pp. 163-180). Madison, Wis: Popular Press 2.

Höflich, Joachim R., \& El Bayed, Afifa (2015). Perception, Acceptance, and the Social Construction of Robots-Exploratory Studies. In Jane Vincent, Sakari Taipale, 
Bartolomeo Sapio, Guiseppe Lugano, \& Leopoldina Fortunati (Eds.), Social Robots from a Human Perspective (pp. 39-54). Springer Verlag.

Kidd, Dustin (2017). Popular Culture. Oxford Bibliographies.

Knellwolf, Christa \& Goodall, Jane(2017). Frankenstein's Science: Experimentation and Discovery in Romantic Culture, 1780-1830. Aldershot, England; Burlington, VT: Routledge.

Larabee, Ann (2018). Frankenforms: The 200th Anniversary of Frankenstein. The Journal of Popular Culture, 51(4), 821-823. https://doi.org/10.1111/jpcu.12713

Lehman-Wilzig, Sam N. (1981). Frankenstein unbound: Towards a legal definition of artificial intelligence. Futures, 13(6), 442-457. https://doi.org/10.1016/0016$\underline{3287(81) 90100-2}$

McQueen, Sean (2014). Biocapitalism and Schizophrenia: Rethinking the Frankenstein Barrier. Science Fiction Studies, 41(1), 120-135. https://doi.org/10.5621/sciefictstud.41.1.0120

Miscione, Gian P. (2015). Las ranas de Galvani, la pila de Volta y el sueño del doctor Frankenstein. Hipótesis, Apuntes Científicos Uniandinos, 18, 56-65. Retrieved from https://studylib.es/doc/5151577/las-ranas-de-galvani--la-pila-de-volta-yel-sueño-del-doctor

Mulkay, Michael (2016). Frankenstein and the Debate Over Embryo Research: Science, Technology, \& Human Values. https://doi.org/10.1177/016224399602100202

Nagy, Peter; Wylie, Ruth; Eschrich, Joey \& Finn, Ed (2018). The Enduring Influence of a Dangerous Narrative: How Scientists Can Mitigate the Frankenstein Myth. Journal of Bioethical Inquiry, 15(2), 279-292. https://doi.org/10.1007/s11673018-9846-9

Nomura, Tatsuya; Sugimoto, Keisuke; Syrdal, Dag S., \& Dautenhahn, Kerstin (2012). Social acceptance of humanoid robots in Japan: A survey for development of the frankenstein syndorome questionnaire. In 2012 12th IEEE-RAS International Conference on Humanoid Robots (Humanoids 2012) (pp. 242-247). https://doi.org/10.1109/HUMANOIDS.2012.6651527

O’Neill, Robert D. (2006). "Frankenstein to futurism": representations of organ donation and transplantation in popular culture. Transplantation Reviews, 20(4), 222-230. https://doi.org/10.1016/j.trre.2006.09.002

Oliveros Aya, César (2015). El sueño de Frankenstein. Hallazgos, 12(23), 117-144. https://doi.org/10.15332/s1794-3841.2015.0023.06

Pardo, Pablo (2018, septiembre 20). Por qué la Inteligencia Artificial necesita clases de ética: "Hemos creado un Frankenstein". El Mundo. Retrieve from https://www.elmundo.es/papel/futuro/2018/09/04/5b883125e5fdea97248b45d6. $\underline{\mathrm{html}}$

Peña Valenzuela, Daniel (2018, febrero 28). Frankenstein o Alexa: La inteligencia artificial en prospectiva. Derecho de los Negocios.Retrieve from https://dernegocios.uexternado.edu.co/comercio-electronico/frankenstein-oalexa-la-inteligencia-artificial-en-prospectiva/

Peters, Ted (2018). Playing God with Frankenstein. Theology and Science, 16(2), 145-150. https://doi.org/10.1080/14746700.2018.1455264 
Riquelme, Rodrigo (2018, enero 22). ¿De quién son los datos que usa la Inteligencia Artificial? El Economista. Retrieve from http://app.vlex.com.wdg.biblio.udg.mx:2048/\#WW/search/*/inteligencia+artifi cial/p4/vid/701354677

Robots made in Chile buscan revolucionar la industria local. (2015, abril 6). El Mercurio. Retrieve from http://www.economiaynegocios.cl/noticias/noticias.asp?id=139267

Rollins, Shannon. (2018). The Frankenstein Meme: The Memetic Prominence of Mary Shelley's Creature in Anglo-American Visual and Material Cultures. In C. Marie Davison \& Margaret Mulvey-Roberts (Eds.), Global Frankenstein (pp. 247-263). Switzerland: Springer.

Ruiz-del-Solar, Javier \& Weitzenfeld, Alfredo (2012). Advances in Robotics in Latin America. Fournal of Intelligent \& Robotic Systems, 66(1-2), 1-2. https://doi.org/10.1007/s10846-011-9629-6

Sá Elias, Paulo (2017, noviembre 20). Algoritmos e inteligência artificial exigem atenção do Direito. Consultor Furídico.Retrieve from https://www.conjur.com.br/2017-nov-20/paulo-sa-elias-inteligencia-artificialrequer-atencao-direito

Sánchez, Verenise (2018, agosto 23). Cuando la inteligencia artificial nos supere. México Ciencia y Tecnología. Retrieve

http://conacytprensa.mx/index.php/reportajes-especiales/23128-cuandointeligencia-artificial-supere

Shelley, Mary (2012). Frankenstein. New York: W. W. Norton \& Company. Apple Books Edition.

Sundar, Shyam; Waddell, T. Frank, \& Jung, Eun H. (2016). The Hollywood Robot Syndrome media effects on older adults' attitudes toward robots and adoption intentions. In 2016 11th ACM/IEEE International Conference on Human-Robot Interaction (HRI) (pp. 343-350). https://doi.org/10.1109/HRI.2016.7451771

Torres, Ariel. (2015, enero 3). La inteligencia artificial no es peligrosa; nosotros, sí. La Nación. Retrieve from https://www.lanacion.com.ar/1757065-la-inteligenciaartificial-no-es-peligrosa-nosotros-si

Tseng, Chun-Yao \& Ting, Ping-Ho (2013). Patent analysis for technology development of artificial intelligence: A country-level comparative study. Innovation, 15(4), 463-475. https://doi.org/10.5172/impp.2013.15.4.463

Tudor, Andrew (1989). Seeing the worst side of science. Nature, 340, 589-592. https://doi.org/10.1038/340589a0

Urrego, Rodrigo A. (2005). Frankenstein y otras historias de terror y miedo. Reflexiones sobre la ciencia y la tecnología. Revista Colombiana de Ciencias Pecuarias, 18(3), 272-275. Retrieved from http://www.scielo.org.co/pdf/rccp/v18n3/v18n3a09.pdf

Van der Laan, James M. (2010). Frankenstein as Science Fiction and Fact. Bulletin of Science, Technology \& Society, 30(4), 298-304. https://doi.org/10.1177/0270467610373822 
Velasco Sánchez, Enrique R. (1996). Inteligencia artificial: una utopía realizada. Perfiles Educativos. (18)74, 65-72. Retrieved

http://www.iisue.unam.mx/perfiles/descargas/pdf/1996-74-65-72

Ziolkowski, Theodore (1981). Science, Frankenstein, and Myth. The Sewanee Review, 89(1), 34-56.

\section{Este texto está protegido por una licencia Creative Commons 4.0}

Usted es libre para Compartir — copiar y redistribuir el material en cualquier medio o formato- y Adaptar el documento - remezclar, transformar y crear a partir del material - para cualquier propósito, incluso comercialmente, siempre que cumpla la condición de:

Atribución: Usted debe reconocer el crédito de una obra de manera adecuada, proporcionar un enlace a la licencia, e indicar si se han realizado cambios. Puede hacerlo en cualquier forma razonable, pero no de forma tal que sugiera que tiene el apoyo del licenciante o lo recibe por el uso que hace. 